\title{
The Determining Factors of Rural Water Supply Pattern in Ugbokolo Community, Benue State- Nigeria
}

\author{
Aper, J.A (Corresponding author) \& Agbehi, S.I \\ Department of Geography, Benue State University \\ PMB 102219, Makurdi, Benue State, Nigeria \\ Tel: 234-703-786-3275 E-mail: jim_aper@yahoo.com
}

Received: December 21, 2010

Accepted: February 14, 2011

doi:10.5539/jsd.v4n2p225

\begin{abstract}
This study examines the pattern of domestic water supply in Ugbokolo community and investigates some of the physical and socio-economic factors that influence the water supply situation in the area. To achieve this, data was collected among 1784 households in 17 settlements in the community. The data was generated using questionnaire, field observations and measurements and analyzed into statistical tables and figures. The results of the dry and wet season patterns of water supply show that streams/rivers contribute $27.89 \%$ and $24.16 \%$, and rainwater as $0.00 \%$ and $27.22 \%$ respectively. Mean daily household water demand in Ugbokolo community is estimated at 155,788 lpd more than the actual available supply of 113,249 lpd leading to shortfalls (29-2,381 lpd) across the community. This pattern of rural water supply is explained (84\%) by conditions such as accessibility to sources of water supply, especially in dry season, government intervention, and availability of technical manpower and community participation in water supply projects maintenance, availability of storage facilities and amount of ground water yield. Water supply management in the community will require regulating the influence of these factors to achieve meaningful supply pattern as well as improve the ability of the people to cope through rainwater harvesting and increased storage of water in the rainy season to minimize the health and sanitation implications of water shortage.
\end{abstract}

Keywords: Determining Factors, Pattern, Rural water, Ugbokolo community, Benue State

\section{Introduction}

Reports by intentional bodies like the United Nations (UN) and World Health Organization (WHO) and other non-governmental organization have indicated that water supply in not always commensurate with demand worldwide. According to WHO (2010) only $32 \%$ of rural population in developing countries have access to safe drinking water. Today, a large percentage of the rural population in developing countries continues to live without adequate access to safe and convenient water supply and sanitation and water supply is still unreliable (Dada, 2009. In Nigeria, more than $90 \%$ of rural areas and $60 \%$ of urban areas face water related problems (ADF, 2007). The daily per capita consumption of water in Nigeria varies between 10-27 litres, with an average of 46 litres, which is far below the internationally recommended minimum requirement of 115 liters per person per day. This shortfall in water requirement is due to differences in availability and supply (Ayoade and Oyebande, 1978, UNICEF, 2009).

Benue State is faced with serious water supply problem. Some studies have been carried out to assess the water supply situation in different parts of Benue State and examine the explanatory factors and implications on the people (Oto, 2000 and Nyiehur, 2000). The common finding is that water scarcity is a recurrent scene in Benue. According to Ifan (2002), the people of Mbatiav district in Gboko Local Government Area of Benue State for example, face water supply shortages with cases of typhoid, cholera, bilharzias, dysentery and guinea-worm. Adyo (2003) also observed that the pattern of rural water supply in Guma Local Government Area of Benue State could not meet the expectation of the people.

To address the problem of water supply, the Benue State government established the Benue State Water Board, Benue State Rural Water Supply and Sanitation Agency (BERWASSA), Ministry of Water Resources and Environment in addition to external interventions from WaterAid UK and UNICEF. These agencies were guided by the responsibility to provide water and alleviate water supply problems in Benue State. Yet, inadequate water supply is still prevalent in many communities such as Ugbokolo community.

Ugbokolo community for example, has a mean household water need of 5,577 lpd of which only 1,325 lpd is available. This situation creates an excess mean household water demand of about 4,252 $\operatorname{lpd}(63 \%)$ (Agbehi, 2007). This study therefore investigates the role of some physical and socio-economic factors in determining the water supply situation in the area.

\section{Materials and Methods}

Ugbokolo community in Okpokwu Local Government is located in the western part of Benue state. The community lies between latitudes $7^{0} 08,00^{\prime \prime} \mathrm{N}$ and $7^{0} 13^{\prime} 48^{\prime \prime} \mathrm{N}$ and longitudes $7^{0} 41^{\prime} 42^{\prime \prime} \mathrm{E}$ and $7^{0} 49^{\prime} 30^{\prime \prime} \mathrm{E}$ (Fig 
1). The area has marked wet and dry seasons, an indication of the Koppen's Aw tropical humid climate type. Rainfall is expected in April-May and lasts till November with peaks in June-July and September-October. Surface drainage of the area is poor as cases of flood are experienced during heavy down pour.

The of geology of the area- the Asata Nkporo shale formation, which offer poor infiltration and ground water storage encourages profuse surface runoff during rains. The fractures in the shale are not inter-connected and maybe be as wide as $30 \mathrm{~cm}$ (Tahal Consultants, 1981). There is no clearly defined ground water level according to available findings and even where found, the water table fluctuates up to $8 \mathrm{~m}$ between the wet and dry seasons. Based on this, there are few or no exploitable ground water reserves in the area.

The major rivers in the area are Mabeh, Abode, Ohimini and Omulewu. These rivers are highly seasonal and dry up in the dry season with some stagnant pools in their channels in dry season. This seasonality of the drainage system creates serious problems to inhabitants of Ugbokolo community, since most of community members depend on natural sources for their water needs. The projected population of the community is estimated at 25,123 persons. The pattern of settlement is predominantly isolated settlements without a definite structure (Fig 2).

Data on sources of water supply were collected from 1784 heads of households using questionnaire, observation and oral interview. House hold units are identified as residential units under a common head. The head of households are mostly involved in the task of mobilizing resources for water supply in communities (Ezenwaji, 2003). Data on quantity of water supply and demand were obtained through household water budgeting using daily water need and water use based on household sizes. The information on water supply factors was isolated from the following parameters which covering physical, technological, social and economic conditions of the community. The parameters were defined as follows:

$\mathrm{X} 1=$ months well yield water per annum

$\mathrm{X} 2$ = Estimated distance to source of water supply in dry season

$\mathrm{X} 3$ = Estimated distance to source of water supply in rainy season

$\mathrm{X} 4=$ Size of storage facilities

$\mathrm{X} 5=$ Number of collapsed boreholes

$\mathrm{X} 6=$ Number of collapsed hand-dug wells

$\mathrm{X} 7=$ Number of water supply sources in dry season

$\mathrm{X} 8=$ Number of water supply sources in rainy season

$\mathrm{X} 9=$ Perceived quality of water supply in dry season

$\mathrm{X} 10=$ Perceived quality of water supply in rainy season

$\mathrm{X} 11=$ Months streams yield water per annum

$\mathrm{X} 12=$ Number of times of water projects maintenance

$\mathrm{X} 13=$ Number of functional water supply facilities

$\mathrm{X} 15=$ Number of times water supply facility fails in a year

X16 $=$ Quality of workforce maintaining water supply projects

X17 $=$ Number of government water supply facilities in the community

$\mathrm{X} 18=$ Number of community water supply facilities in the community

$\mathrm{X} 19=$ Number of water sources restricted from public use

Variables X1, X7, X8, X11, X17, X18 and X19 were determined through the use of questionnaire and X2 and $\mathrm{X} 3$ were measured based on estimated distances between settlement centres and water source. Data on X4, X5, $\mathrm{X} 6, \mathrm{X} 13$ and X14 were obtained based on observations and X9, X10, X15, and X16 were evaluated using a rating scale of 0-5 representing the least to the highest impacts of the prevailing conditions. Descriptive statistics such as mean and percentages were used in addition to principal components analysis (PCA) in summarizing and analyzing the data. PCA was used to identify the principal dimensions of the selected variables responsible for water supply in the study area to identify their relative contributions in influencing water supply in the community. The PCA was executed using the Statistical Package for the Social Sciences (SPSS) based on the Kaiser's normalization and rotated variable maximization (varimax) principles (Kaiser, 1959). The PCA analysis generated both the correlation matrix and the rotated components matrix, in which only components with eigen-values above unity with $5 \%$ or more explanatory powers considered as separate orthogonal dimensions or factor components (Anyadike, 2009).

\section{Results and Discussion}

\subsection{Sources of Water Supply in Ugbokolo Community}

The water sources available to households in Ugbokolo community include streams/rivers, rainwater, hand-dug wells, boreholes and water vendors. About 1,702 (27.89\%) and 1,474 (24.16\%) households in the community get 
water from stream/river in the dry and rainy seasons respectively. However, 1,661 households (27.22\%) get water from rainwater in the rainy season, while in the dry season this source of water contributes nothing due to absence of rainwater storage. Responses show that $409(6.70 \%)$ and $560(9.18 \%)$ households obtain water from hand-dug wells in both seasons respectively. Boreholes contribute water supply to 17 household in the wet season $(0.28 \%)$ while 41 respondents $(0.67 \%)$ get their water supply from boreholes in the dry seasons. Also about $90(3.11 \%)$ and 68 households $(1.11 \%)$ get water from vendors in dry and rainy seasons respectively (Table 1).

In Ugbokolo community, settlements that access hand-dug wells are those that have the facilities in their area like Odessassa, Aobida, Ondo, Akpali, Okwungaga, Aochichodo, Ankpa and Akpeke. The wells in Ankpa however dry up after rains and well water in Akpeke settlement is muddy in the rainy season because of sediments. Boreholes exist in Odessassa, Aobida And Okwungaga and the percentage water supply contribution is mostly limited to the immediate environment. In Odessassa, the limitation of boreholes is complemented by the services of water vendors who draw from the water scheme that is not functional in all parts of Odessassa. On a general note, the households in Ugbokolo community use mainly water from streams/rivers, and less of hand-dug wells, boreholes and rainwater. The major sources are sometimes inadequate making some parts of the community to depend also on water vendors. The water quality from streams cannot be guaranteed and the vendors also use unsafe storage to transport water. Thus the problem of domestic water in Ugbokolo community just like most communities in developing countries is that of quantity, and then quality.

\subsection{Variations in Water Demand in Ugbokolo Community}

In most communities in developing countries, the quantity of water needed is more than supply. It has been established that the water needs of the people of Ugbokolo community also vary among settlements depending on intensity of natural and socio-economic conditions. The domestic demand for water exceeds water availability and by implication, shortage of water supply is generally experienced in the area. For example, Odessassa settlement needs 75,656 lpd of water, Effa needs 14,921 litres, Aobida, 7,390, Ondo, 6,612, Aokpe, 7,264, Akpali, 7,054 and Aikpla 5,283 per day to meet their water needs. Also, Okungaga, Efeche, Ola-Eja, Ola-Okpe, Ankpa, Akpeke and Aochichodo need 5,292, 4, 484, 3,9441, 3,009, 3,551, 3,043, 3,184 litres of water daily to satisfy their water needs. Mabeh-Ehaje, Afujo and Ohimini also require varying quantities of water to meet their domestic needs (Table 2).

Odessassa has the highest water demand while Ohimini has the least. This could be as a result of the large population in Odessassa and small number households in Ohimini. Some of these settlements have more households, engage in local industrial activities such as cassava (garri) processing and palm oil production. These could make some settlements demand for more water daily than others. The percentage water demand in the entire Ugbokolo community is highest in Odessassa (49\%) with the obvious reason that more people reside there than any other part of Ugbokolo community and lowest in Mabe-Ehaje,Afujo and Ohimini with 1\% each. These three settlements have less households, hence the low percentage of water demand.

\subsection{Variation in Pattern of Domestic Water Supply in Ugbokolo Community}

The amount of water consumed in the settlements of the community is as varied as demand, but below demand. None of the settlements has water satisfaction. For example, Odessassa requires $75,656 \mathrm{lpd}$, but only $51,849 \mathrm{lpd}$ is available, a difference of 23,8071 lpd (Table 3). Ohimini settlement has the highest (82 lpd) per capita water consumption and Ola-Okpe has the least (54). The differences could emanate from the various economic status of different settlements or available of water supply in the settlements. The status of water supply depends on water supply needs and quantity made available for use as at when needed. According to Chima (1988), household water consumption equals household water availability. None of the households in the study area according to responses is connected to any kind of central water supply, except the Benue State Polytechnic, Ugboloko, within Odessassa benefit from piped water services.

\subsection{Spatial Variability of Water Supply Deficiency in Ugbokolo Community}

The spatial pattern of water deficiency across the settlements shows that the mean per capita household water need for Ugbokolo community is $1512 \mathrm{lpd}$ as against the per capita household water supply of 1,147 lpd (Table 4). This indicates a per capita household water supply needed in the community to about 365 lpd representing about $73 \%$ of the per capita household water needed but not met by supply. This overall picture of the variation in community water deficiency is represented in Fig. 3. Drawing from the water deficiency situation, there is relatively low water shortage in Odessassa (31\%), which is the most urbanized and populated settlement in the community. This is explained by the facts that residents are civil servants and businessmen and have money to dig hand-dug wells and engage the services of vendors as others alternatives to the natural sources. Residents in Odessassa however walk about $0.7 \mathrm{~km}$ and $1.2 \mathrm{~km}$ in rainy and dry seasons respectively to access their water needs from streams.

The water shortage situation in respect of Okwungaga (29\%) could be as a result that most boreholes and hand-dug wells available to households are not functional and the few functional ones are overstretched in the dry season households have to travel an average distance of $0.8 \mathrm{~km}$ in both dry and rainy seasons to get supplementary water from streams. The Efeche settlement which has access to a perennial stream within an average distance of about $0.6 \mathrm{~km}$ in both dry and rainy season, still records high deficiency of $29 \%$. This could be 
as result of water quality in dry season emanating from reduction in volume and presence of turbidity in the water during rainy season as a result of washed polluted into the stream.

Mabeh-Ehaje settlement has $27 \%$ deficiency. This is expected as the river (River Mabeh) in the study area is about $0.5 \mathrm{~km}$ and but quality of water in wet season is muddy and infested with decayed leaves in the dry season. This $27 \%$ deficiency could be as a result of quality of this river in both seasons of the year. Heavy rainfall as gathered from interview changes the colour of the river thereby making people of the area to look for alternative sources of water supply. The settlement with the lowest deficiency is Ola-Eja and Aokpe (19\%). Both settlements are located closest to the largest river (Mabeh) in the community. The river Mabeh is perennial and is about $0.5 \mathrm{~km}$ away from any part of the settlement and yields water throughout the year, though the reported quality is doubtful. In summary, water shortage variation of between $19-35 \%$ among the settlements which is an indication of the uneven water availability situation in Ugbokolo community.

\subsection{Factors determining the water supply pattern in Ugbokolo community}

From the correlation pattern of the water supply variables, there are a number of positive and negative correlations between and among the selected variables. By implication, associative and inverse relationships exist from the interaction of the variables that influence water supply in the study area. Correlation coefficients of \pm 0.70 are considered significant at 0.5 confidence level (one-tailed). Thus there is a significant positive correlation between variables X17 (0.99) and X12, X6 with X14(0.96), X1(0.98) with X13, X12 with X12(0.88), $\mathrm{X} 1$ with $\mathrm{X} 14(0.88)$ and $\mathrm{X} 1(0.88)$ with X6. Also, X6(0.87) significantly correlates with X13, X2(0.86) with X17, with X18(0.74), X18 with X12(0.72) and X13 with X18(0.72). The relationships between some variables are weak. However, no particular pattern can be deduced from these relationships. There are instances of autocorrelation and multiple relationships among some variables.

The problems of lack of a clear explanatory pattern and mixed relationships among variables in the correlations were resolved through the use of principal components. On the basis of the Kaiser principle, six components were extracted using the variable maximization (varimax) method with eignvalues of $6.65,3.58,1.94,1.48,1.24$ and 1.08 and percentage contributory variances of $35 \%, 19 \%, 10 \%, 8 \%, 7 \%$ and $6 \%$ respectively. These (6) components produce a number of significant parameters (in parentheses) that define the factors which explain variation in water supply in the study area. Only variables with coefficient of $+/-.70$ and above are considered significant (at 0.5 confidence level) (Table 5).

Component I has high positive loadings on variables X1 (number of months well yields water per annum), X6 (collapsed hand-dug wells), X13 (available functional water supply facilities) and X14 (non-functional water supply facilities). This component has an eignvalue of 4.86 and account for $35 \%$ of the variation in water supply in Ugbokolo community. This component explains the efficiencies of water supply sources as a factor of water supply in the study area.

Component II loads positively on X2 (estimated distance form sources of water in the dry season), X17 (presence of government water projects) and X12 (number of times water projects are maintained in one year). The factor component has eignvalue of 4.02 and offers additional influence of $19 \%$ bringing cumulative explanation of water supply to $54 \%$. This component best explains regularity of water supply in the community as a factor of water supply.

In addition, component III loads significantly on variables X15 (number of times water supply projects fail in a year) and X16 (number of water maintenance workforce) with negative and positive coefficients of -0.85 and 0.88 respectively. This means the frequency of water facility failure which can be reduced by increased work force can regulate water availability. It has eignvalue of 2.06 and $10.0 \%$ variation raising the cumulative explanation to $64 \%$. This component describes the factor of water supply maintenance in the study area as affecting water supply.

Component IV is defined by variable X8 (number of sources of water supply during rainy season) with a coefficient of -0.82 . This component best explains the contributions of natural sources of water supply in the community. It has an eigen-value of 1.88 and explains variation of $8 \%$ and brings cumulative explanation to $72 \%$.

Component $\mathrm{V}$ has negative and positive loadings on X3 (estimated distance to water in rainy season) and X6 (size of container for water storage) with coefficients -0.77 and 0.77 respectively. The inverse significance of distance in rainy season in relation to direct relationship with size of storage means that the further the distance, the larger the storage facilities needed to maintain steady supply. It has eigen-value of 1.88 and explains variation of $6 \%$ offering a cumulative explanation of $78 \%$. This factor exemplifies community participation.

The final component, component 6 has X11 (period streams yield water per annum) as the only significant variable with coefficient of 0.74 . It has eignvalue of 1.27 and explains $6.00 \%$ of variation with cumulative percentage of 84.00 . The component best explains the reliability of stream water, a major natural source of water supply, in the community. From the analysis above, it has shown that six components representing different factors explain $84.00 \%$ of the variation in water supply in the study area. According to the analysis, the variables offering the components are described as the major factors affecting water supply in the study area. The 
remaining factors not captured in this study are redundant and contributing only $16 \%$ remaining explanation of variation in water supply situation in Ugbokolo Community.

\section{Conclusion}

Based on the study, it is concluded that streams, rivers and hand-dug wells are the major sources of water in Ugbokolo and the situation of water supply is that the water demand of the people is not met; hence, there is high prevalence of water supply shortage and associated problems. Also, 16 settlements out of 17 have no water supply facility and very few community water projects are available to complement natural water supply sources like streams and rainwater. Also, water in the study area should be treated most especially in the dry season before drinking to prevent incidences of disease, since there is high pressure on few existing sources leading to high tendency of pollution. It is also observed that inefficiencies of sources of water supply, poor access to sources of water supply in dry season and poor government intervention, as well as availability of manpower and community participation in water supply projects, low storage facilities and geology are the major factors that affect water supply in Ugbokolo community.

To alleviate the water supply problem, it is recommended that water supply to the settlements should be improved through external assistance by supply of water supply facilities. Where facilities already exist, the community should be trained to maintain water supply facilities and mobilized to engage in water supply projects that should complement government's efforts. The community in the study area should be empowered financially to enable them dig hand-dug wells and maintain them. The community should adopt other coping measures like water treatment and storage to alleviate the socio-economic and health impact of scarcity on the community.

\section{References}

African Development Fund (ADF). (2007). Rural water supply and sanitation sub-programmes in Yobe and Osun States of Nigeria-Appraisal report. Water and Sanitation Department (OWAS), May, 2007.

Adyo, A.U. (2003). Factors responsible for rural water scarcity in Guma L.G.A of Benue State. Unpublished B.Sc. Project, Department of Geography, Benue State University, Makurdi, Nigeria.

Agbehi, I.S. (2000). Spatial analysis of bus-passenger movement (flow) from selected towns in Benue State. Unpublished B.Sc Project, Department of Georaphy, A.B.U, Zaria, Nigeria.

Agbehi, I.S. (2007). Assessment of domestic water supply in Ugbokolo community, Okpokwu LGA, Benue State. Unpublished M.Sc. Project, Department of Geography, Benue State University, Makurdi.

Anyadike, R.N.C. (2009). Statistical Methods for Social and Environmental Sciences. Ibadan: Spectrum Books, (Chapter 7).

Ayoade, J.O. \& Oyebande, L. (1978). Water resources. In J.S. Oguntoyinbo (ed): A geography of Nigeria development(pp. 180-235). Ibadan:Heinemann Educational Books Ltd.

Dada, A.C. (2009). Sachet water phenomenon in Nigeria: Assessment of the potential health impacts, African Journal of Microbiology Research Vol.3 (1) pp. 015-021.

Ezenwaji, E.E. (2003). Improved Water Supply as a Strategy for Poverty Alleviation in the Rural Area of Anambra State, Nigeria. Environment and Poverty in Nigeria (ed). Jamoe Enterprises, (Nig).

Ifan, A.B. (2002). The problem of water supply in Mbatiav district in Gboko LGA of Benue State, Nigeria. Unpublished B.sc Project, Benue State University, Makurdi, Nigeria.

Kaiser, H.F. (1959). Computer programme for varimax rotation in factor analysis. Educational Psychological Measurement, Vol. 19, Pp 413-420.

Nyiehur, M.W. (2000). Water scarcity and its socio-economic implications on the people of Mbalam and Ugee council wards of Gwer LGA. Unpublished B.Sc. Project, Department of Geography, Benue State University, Makurdi, Nigeria.

Oto, J.A. (2000). Assessment of domestic water supply in north-bank area of Makurdi town. Unpublished B.Sc. Project, Department of Geography, Benue State University, Makurdi, Nigeria.

Tahal Consultants. (1981). Benue State Water Corporation: Priority water supply scheme. N0 B-11, Ugbokolo Design Report, pp 15-17.

UNICEF. (2009). The one million water and sanitation (WASH) intiative-baseline survey report on Zimbabwe. Nairobi:WE Consult Lda.

W HO \& UNICEF. (2010). Water and sanitation update 2010. 20 Avenue Appia, 1211 Geneva 27, Switzerland: WHO Press. 
Table 1. Contribution of Sources of Water Supply in Ugbokolo Community

\begin{tabular}{|c|c|c|c|c|c|c|c|c|c|c|c|}
\hline \multirow[b]{3}{*}{ Settlements } & \multicolumn{10}{|c|}{ Dry and Wet Season Water Sources in the Community } & \multirow[b]{3}{*}{ Total } \\
\hline & \multicolumn{2}{|l|}{ STR } & \multicolumn{2}{|c|}{ RNW } & \multicolumn{2}{|c|}{ HDW } & \multicolumn{2}{|c|}{ BRH } & \multicolumn{2}{|l|}{ VND } & \\
\hline & $\mathrm{D}$ & W & $\mathrm{D}$ & W & $\mathrm{D}$ & W & $\mathrm{D}$ & W & $\mathrm{D}$ & W & \\
\hline Odessassa & 612 & 432 & 0 & 795 & 34 & 461 & 10 & $1^{1}$ & 190 & 68 & 2933 \\
\hline Effa & 243 & 202 & 0 & 143 & 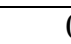 & 0 & 0 & ( & 0 & 0 & 588 \\
\hline Aobida & 79 & 76 & 0 & 76 & 4 & 42 & 2 & 2 & 0 & 0 & 323 \\
\hline Ondo & 102 & 95 & 0 & 71 & 2 & 2 & 0 & 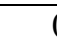 & 0 & 0 & 272 \\
\hline Aokpe & 72 & 71 & 0 & 72 & ( & $\mathrm{c}$ & 0 & ( & 0 & 0 & 215 \\
\hline Akpali & 96 & 101 & 0 & 72 & 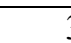 & 3 & 0 & 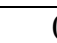 & 0 & 0 & 275 \\
\hline Aikpla & 65 & 90 & 0 & 72 & 1 & c & 0 & ( & 0 & 0 & 210 \\
\hline Okungag & 56 & 56 & 0 & 54 & . & 7 & 5 & 2 & 0 & 0 & 204 \\
\hline Efeche & 53 & 52 & 0 & 53 & 7 & $\mathrm{c}$ & ( & 7 & 0 & 0 & 158 \\
\hline Ola-Eja & 78 & 68 & 0 & 50 & ( & $\mathrm{c}$ & 0 & ( & 0 & 0 & 196 \\
\hline Ola-Okpe & 50 & 40 & 0 & 43 & ( & $\mathrm{c}$ & 0 & ( & 0 & 0 & 133 \\
\hline Ankpa & 39 & 39 & 0 & 38 & ( & 37 & 0 & ( & 0 & 0 & 155 \\
\hline Akpeke & 43 & 40 & 0 & 31 & 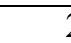 & 0 & 0 & ( & 0 & 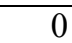 & 112 \\
\hline Aochichs & 32 & 32 & 0 & 32 & 3 & $\varepsilon$ & 0 & ( & 0 & ( & 107 \\
\hline Mabe-Ehaje & 36 & 36 & 0 & 26 & 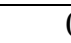 & ( & 0 & ( & 0 & ( & 98 \\
\hline Afujo & 33 & 31 & 0 & 20 & ( & ( & 0 & ( & 0 & 0 & 84 \\
\hline Ohimini & 13 & 13 & 0 & 13 & ( & ( & 0 & ( & 0 & 0 & 39 \\
\hline Total & 1702 & 1474 & $\mathbf{0}$ & 1661 & 40 & 56 & 17 & 4 & 190 & 68 & 6102 \\
\hline$(\%)$ & 28.9 & 24.2 & $\mathbf{0}$ & 27.2 & 6.' & 9.2 & 0.3 & 0.' & 3.1 & 1.1 & 100 \\
\hline
\end{tabular}

$\mathrm{STR}=$ streams/rivers, $\mathrm{RNW}=$ rainfall, $\mathrm{HDW}=$ hand dug wells, $\mathrm{BRH}=$ boreholes, $\mathrm{VND}=$ =endors, $\mathrm{D}=$ =Dry, $\mathrm{W}=\mathrm{Wet}$

Table 2. Daily Domestic Water Demand in Ugbokolo Community (litres)

\begin{tabular}{|l|r|r|r|}
\hline Settlement & & & \\
& PCD & TWD & \% TWD \\
\hline Odessassa & 87 & 75,656 & 48.56 \\
\hline Effa & 83 & 14,921 & 9.58 \\
\hline Aobida & 91 & 7,390 & 4.74 \\
\hline Ondo & 86 & 6,612 & 4.24 \\
\hline Aokpe & 101 & 7,264 & 4.66 \\
\hline Akpali & 97 & 7,054 & 4.58 \\
\hline Aikpla & 96 & 5,283 & 3.39 \\
\hline Okungaga & 95 & 5,292 & 3.40 \\
\hline Efeche & 85 & 4,484 & 2.88 \\
\hline Ola-Eja & 77 & 3,994 & 2.56 \\
\hline Ola-Okpe & 70 & 3,009 & 1.98 \\
\hline Ankpa & 91 & 3,551 & 2.28 \\
\hline Akpeke & 90 & 3,043 & 1.95 \\
\hline Aochichodo & 100 & 3,184 & 2.04 \\
\hline Mabe-Ehaje & 77 & 2,077 & 1.38 \\
\hline Afujo & 81 & 1,610 & 1.03 \\
\hline Ohimini & 105 & 1,364 & 0.88 \\
\hline Total & $\mathbf{1 5 1 2}$ & $\mathbf{1 5 5 , 7 8 8}$ & $\mathbf{1 0 0}$ \\
\hline
\end{tabular}

PCD $=$ Per Capita Demand; TWD=Total Water Demand 
Table 3. Daily Household Water Consumption in Ugbokolo Community (litres)

\begin{tabular}{|l|r|r|r|}
\hline Settlement & PWC & TWC & \% TWC \\
\hline Odessassa & 60 & 51849 & 45.78 \\
\hline Effa & 64 & 11506 & 10.16 \\
\hline Aobida & 70 & 5596 & 4.94 \\
\hline Ondo & 66 & 5087 & 4.49 \\
\hline Aokpe & 81 & 5864 & 5.18 \\
\hline Akpali & 77 & 5609 & 4.95 \\
\hline Aikpla & 71 & 3918 & 3.46 \\
\hline Okungaga & 69 & 3778 & 3.34 \\
\hline Efeche & 60 & 3199 & 2.82 \\
\hline Ola-Eja & 64 & 3304 & 2.92 \\
\hline Ola-Okpe & 54 & 2434 & 2.15 \\
\hline Ankpa & 71 & 2806 & 2.48 \\
\hline Akpeke & 58 & 1983 & 1.75 \\
\hline Aochichodo & 76 & 2444 & 2.16 \\
\hline Mabe-Ehaje & 56 & 1513 & 1.34 \\
\hline Afujo & 65 & 1290 & 1.14 \\
\hline Ohimini & 82 & 1069 & 0.94 \\
\hline Total & $\mathbf{1 , 1 4 4}$ & $\mathbf{1 1 3 , 2 4 9}$ & $\mathbf{1 0 0}$ \\
\hline
\end{tabular}

PWC-per capita water consumption, TWC-total water consumption

Table 4. Pattern of Water Supply Shortage in Ugbokolo Community (litres per day)

\begin{tabular}{|l|l|l|l|l|l|l|l|}
\hline \multirow{2}{*}{ Settlement } & \multicolumn{6}{|l|}{ Water Demand and Shortage Situation in Ugbokolo Community } \\
\cline { 2 - 8 } & PCD & MHC & PCN & MHN & \%WC & \%WD & TOD \\
\hline Odessassa & 60 & 5185 & 87 & 7566 & 69 & 31 & 2381 \\
\hline Effa & 64 & 1151 & 83 & 1492 & 77 & 23 & 341 \\
\hline Aobida & 70 & 560 & 91 & 739 & 76 & 24 & 179 \\
\hline Ondo & 66 & 509 & 86 & 662 & 77 & 23 & 153 \\
\hline Aokpe & 81 & 586 & 101 & 726 & 81 & 19 & 140 \\
\hline Akpali & 77 & 561 & 97 & 705 & 80 & 20 & 144 \\
\hline Aikpla & 71 & 392 & 96 & 528 & 74 & 26 & 136 \\
\hline Okungaga & 69 & 378 & 95 & 529 & 71 & 29 & 151 \\
\hline Efeche & 60 & 320 & 85 & 448 & 71 & 29 & 128 \\
\hline Ola-Eja & 64 & 330 & 77 & 399 & 82 & 17 & 69 \\
\hline Ola-Okpe & 54 & 243 & 70 & 301 & 81 & 19 & 58 \\
\hline Ankpa & 71 & 281 & 91 & 355 & 79 & 21 & 74 \\
\hline Akpeke & 58 & 198 & 90 & 304 & 65 & 35 & 106 \\
\hline Aochi-Chodo & 76 & 244 & 100 & 318 & 77 & 23 & 74 \\
\hline Mabel-Ehaje & 56 & 151 & 77 & 208 & 73 & 27 & 57 \\
\hline Afujo & 65 & 129 & 81 & 161 & 80 & 20 & 32 \\
\hline Ohimini & 82 & 107 & 105 & 136 & 79 & 21 & 29 \\
\hline Total & 1147 & 11,325 & 1512 & 15,577 & 73 & 27 & 4,25 \\
& & & & & & & 2 \\
\hline
\end{tabular}

Note: PCD-Daily per capita water consumed, MHD-Mean hosehold water consumed,

PCN-Per capita household water need, PCN-Per capita water need, \%WC-water consumption, \%WD-water deficiency, TOD-total water demand.

Source: Authors fieldwork 2010 
Table 5. Principal component matrix of water supply factors in Ugbokolo community

\begin{tabular}{|c|c|c|c|c|c|c|}
\hline \multirow[t]{2}{*}{ Variables } & \multicolumn{6}{|c|}{ Water Supply Factor Components } \\
\hline & I & II & III & IV & $\mathrm{V}$ & VI \\
\hline $\mathrm{X} 1$ & $(.92)$ & .14 & .06 & .06 & .01 &.-12 \\
\hline $\mathrm{X} 2$ & .02 & .97 & -.03 &.-03 & .03 & .10 \\
\hline $\mathrm{X} 3$ & -.15 & .33 & .08 & .08 & .03 & .08 \\
\hline $\mathrm{X} 4$ & .50 & -.10 & .07 & .07 & .22 & .-03 \\
\hline $\mathrm{X} 5$ & -.15 & .32 & .06 & .06 & .58 &.-04 \\
\hline $\mathrm{X} 6$ & $(.98)$ & .16 & .11 & .11 & .05 & .17 \\
\hline $\mathrm{X} 7$ & -.06 & .56 & .17 & .17 & .47 &.-31 \\
\hline $\mathrm{X} 8$ & -.30 & .14 & .03 & .03 & $(.-82)$ & .02 \\
\hline $\mathrm{X} 9$ & .47 & .48 & -.06 &.-06 &.-09 & .37 \\
\hline $\mathrm{X} 10$ & -.42 & .02 & .16 & .16 & .49 &.-12 \\
\hline $\mathrm{X} 11$ & -.06 & .26 & .26 & .26 & .29 & $(.74)$ \\
\hline $\mathrm{X} 12$ & $(.91)$ & .10 & .24 & .24 &.-04 & -.08 \\
\hline $\mathrm{X} 13$ & .95 & .08 & .18 & .18 & .02 & .12 \\
\hline $\mathrm{X} 14$ & -.35 & -.19 & $(.85)$ & $(.85)$ & .20 & .05 \\
\hline $\mathrm{X} 15$ & .12 & .05 & $(.88)$ & $(.88)$ & .33 & -.05 \\
\hline $\mathrm{X} 16$ & .23 & .92 & .15 & .15 & .10 & -.06 \\
\hline $\mathrm{X} 17$ & .58 & .56 & 40 & .40 &.-07 & .07 \\
\hline $\mathrm{X} 18$ & .30 & (.87) & .33 & .33 & .32 & .64 \\
\hline X19 & .19 & $(.97)$ & .15 & .15 & .12 & -.05 \\
\hline Eigen-value & 4.86 & 4.02 & 2.06 & 1.88 & 1.88 & 1.27 \\
\hline$\%$ Variance & 26.0 & 21.0 & 11.0 & 10.0 & 10.0 & 07.0 \\
\hline$\%$ Cum. Expl & 26.0 & 47.0 & 58.0 & 67.0 & 77.0 & 84.0 \\
\hline
\end{tabular}

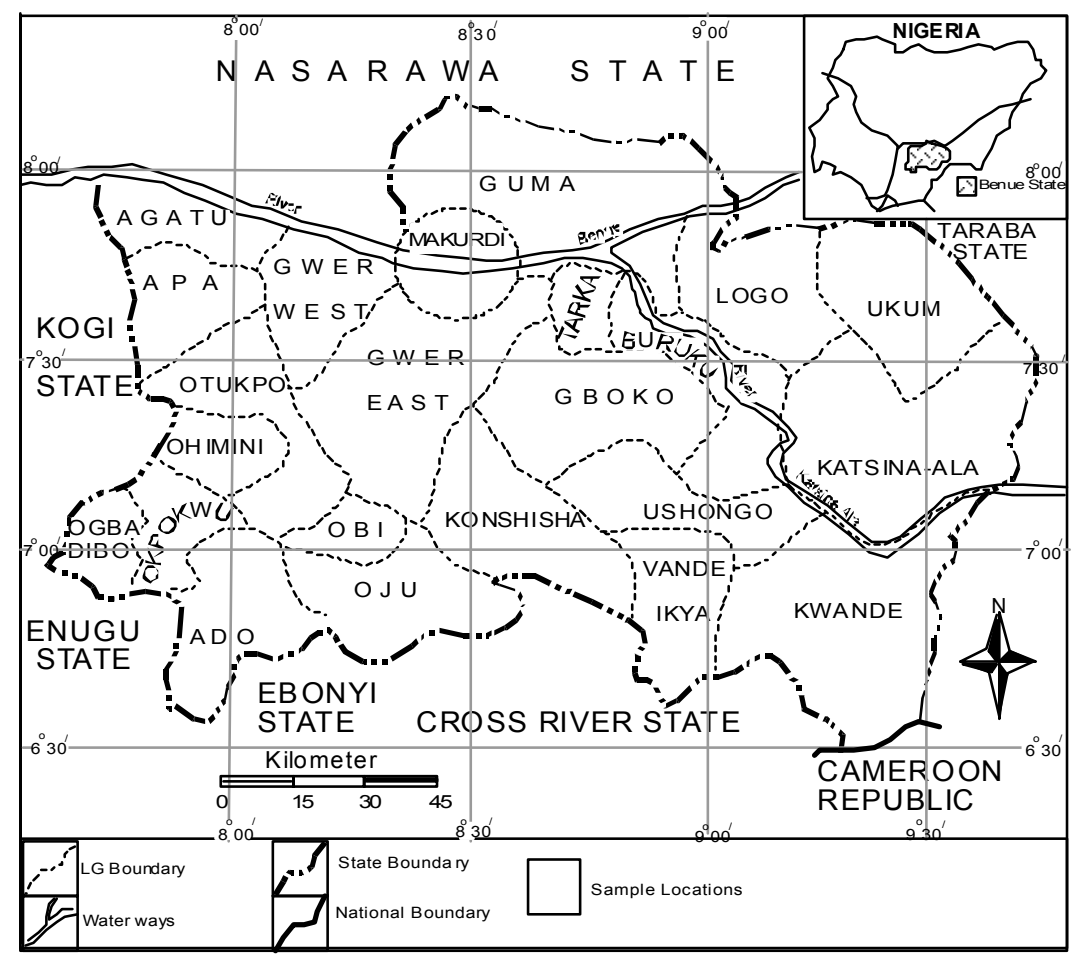

Fig 1: Map of Benue State Showing Okpokwu Local Government Area Source : Ministry of Lands and Survey Makurdi 


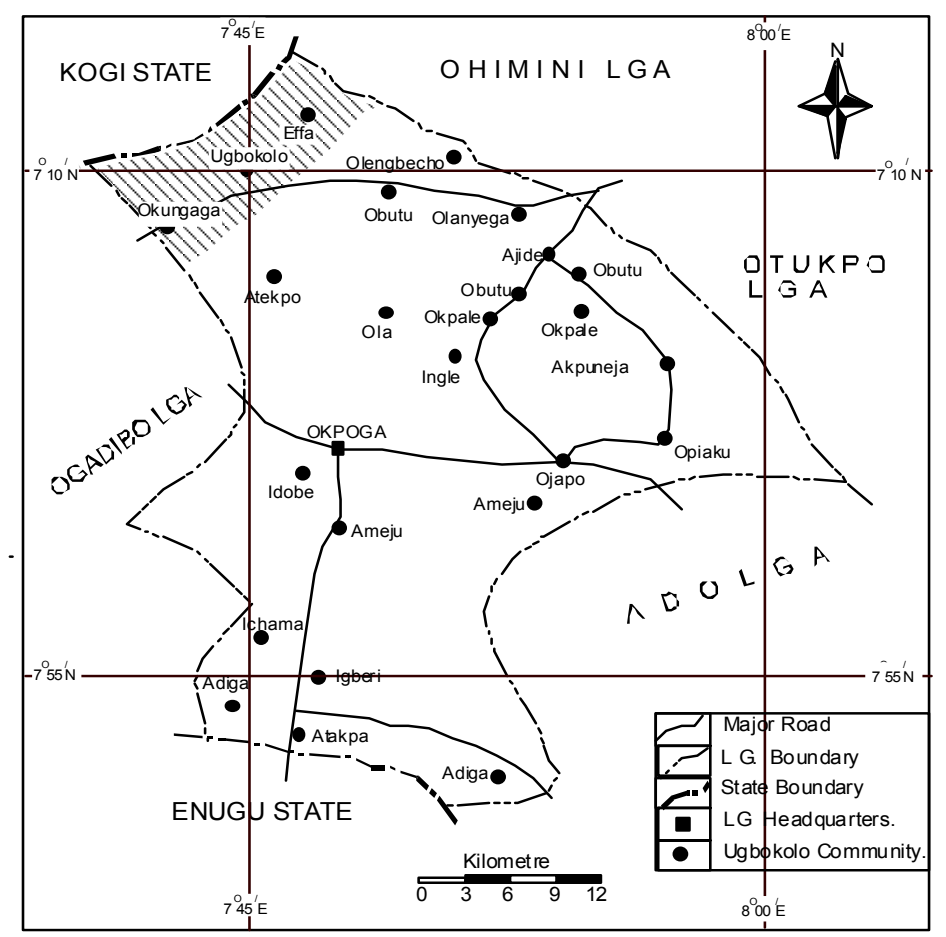

Figure 2. Okpokwu LGA showing Ugbokolo Community Source: Ministry of lands and survey, Makurdi

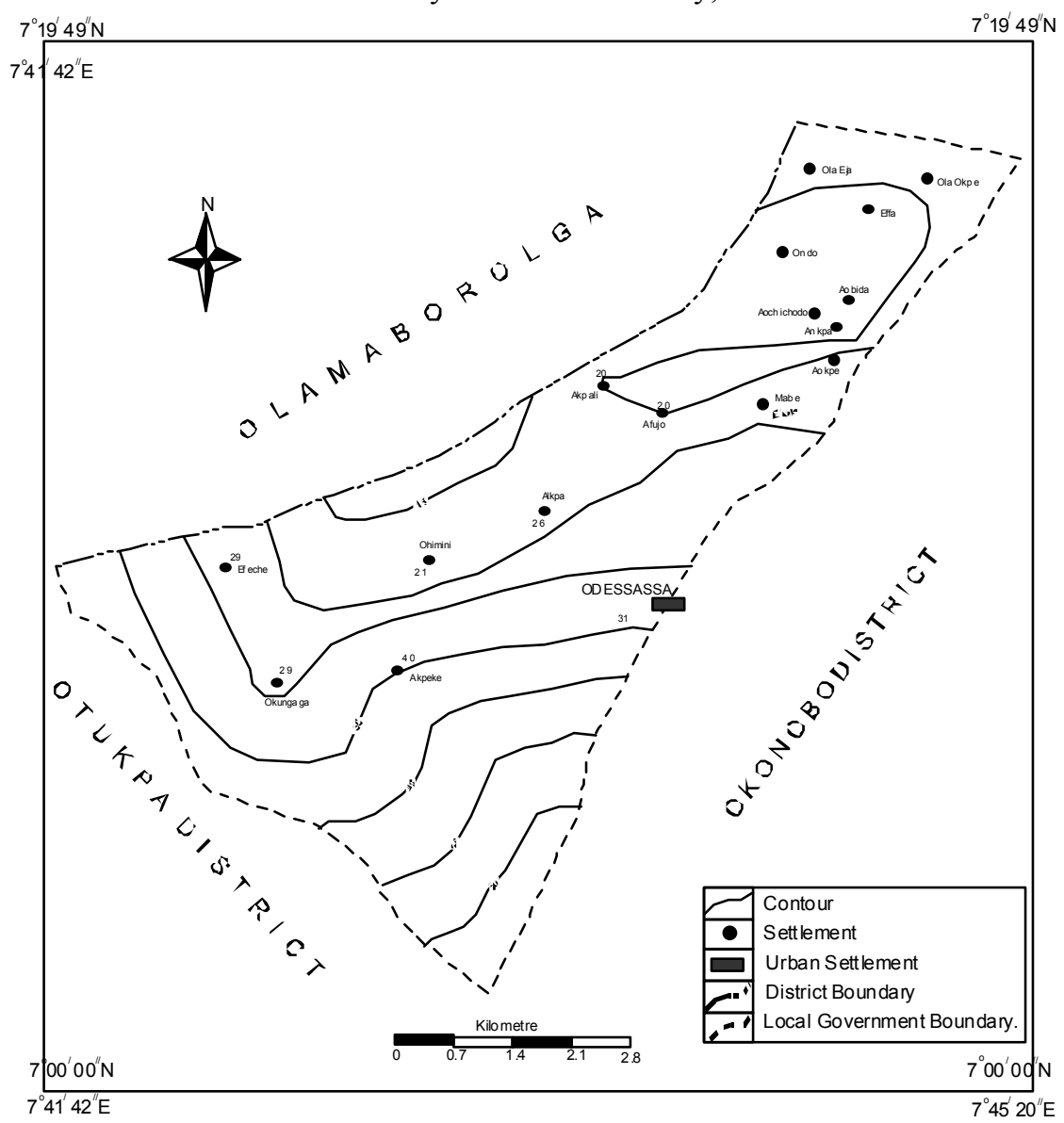

Figure 3. Spatial pattern of water supply deficiency in Ugbokolo Community 